\title{
Pedro Bala: Peter Pan no Brasil
}

\section{Maura Böttcher Curvello*}

\begin{abstract}
Resumo: O presente ensaio coteja as obras Peter Pan, de James Matthew Barrie, e Capitães da Areia, de Jorge Amado, com vistas a verificar como as narrativas representam a criança abandonada da Inglaterra e do Brasil no início do século XX. Frutos de diferentes ideologias, os romances revelam visões que em alguns aspectos se aproximam e, em outros, se repelem. O foco narrativo é, em ambos os livros, fundamental para que se consiga vislumbrar a mundividência dos autores.
\end{abstract}

\begin{abstract}
This assay collates the work Peter Pan, by James Matthew Barrie, and Capitães da Areia, by Jorge Amado, in order to see how the stories present an abandoned child in England and Brazil at the beginning of the twentieth century. Fruits of different ideologies, the novels reveal insights about the portrait of childhood similar in some aspects, and different in others. The narrator is, in both books, essential for one to glimpse the ideology of the authors.
\end{abstract}

Keywords: childhood; violence; abandonment.

Tanto Peter Pan quanto Capitães da Areia são livros que parecem ter o intuito de instruir o leitor de acordo com os princípios e valores de seus escritores. Ambas as narrativas transmitem princípios e diretivas que sugerem a visão crítica de seu autor sobre sua época, e sugestões para alterarem fatos de que discordam.

Ao leitor atento, a narrativa de Capitães da Areia traz à lembrança algumas cenas de Peter Pan. Trata-se de meninos perdidos, estes se deparam, em determinado momento, com uma menina que figura como mãe para alguns, irmã para outros e namorada para o líder do bando. Assim, cabe apresentar nossas considerações acerca dessa similaridade.

Em 1904, Peter Pan foi primeiro publicado e Capitães da Areia, em 1937. O contexto da Inglaterra do final do século XIX e início do século XX, e do Brasil da década de 30 assemelham-se em alguns aspectos. A desigualdade social, a pobreza e, com ela, a desnutrição, o analfabetismo e a mortalidade infantil eram comuns nos dois países. Pesquisas inglesas indicam que, no início do século XX, 25\% da população estavam em estado de pobreza, $15 \%$, em nível de subsistência e cerca de $10 \%$, abaixo do nível de subsistência. A situação da criança era grave não só nas classes inferiores. Havia o sistema de castigos corporais a trabalhadores mirins, considerados preguiçosos e a alunos com dificuldades de aprendizagem. Crianças eram punidas com açoite de cana ou tiras de couro nas mãos ou nas

\footnotetext{
* Mestra e Doutoranda em Letras pela Universidade São Paulo, especialista em análise de textos românticos.
} 
costas, ou ainda tinham suas cabeças mergulhadas em água. A vida escolar não atraía, antes repelia pela rigidez com que se tratava um educando, considerado adulto em miniatura. Além disso, a criança pobre era ainda mais danificada, pois a mendicância era motivo de apreensão de menores em reformatórios, por serem considerados futuros delinquentes.

Sob este ônus, não havia saída para os que não se adequavam aos padrões. Mesmo o riso sem motivo ou a gargalhada ruidosa não eram bem vistos. Afinal, tomados como índice de insensatez, sugerem uma espontaneidade perigosa que pode suscitar a rebelião, pois afrontam a sisudez, a prudência, o bom senso e revelam um estado de alma despreocupado com as convenções.

No Brasil, o trabalho da criança pobre foi e ainda é muitas vezes justificado como uma maneira de tirá-la da rua e das brincadeiras malvistas, pois a disciplina e o tempo ocupado em um emprego eram (são?) considerados uma forma de modelar o comportamento. Nas matérias sobre o trabalho infantil dos jornais da década de 1930, não há críticas à atividade, pois é vista como meio de amenizar a situação de pobreza. Por outro lado, a sociedade desvalorizava o menor trabalhador, somente as crianças que tinham acesso à escola eram bem consideradas.

\begin{abstract}
a maioria das escolas secundárias, destinada às crianças e jovens de 12 a 18 anos, até meados dos anos de 1940, pertencia à iniciativa privada e esses cursos secundários, recentemente organizados com a Reforma Francisco Campos em 1931, apresentavam vasta abrangência de conteúdos, um sistema rígido de avaliação, afastando boa parte da população que não se via representada nessa escola e não deixando dúvidas sobre o caráter elitista desse grau de ensino na época. (ANDREOTTI, s/d, p.11)
\end{abstract}

Nesse contexto, o indivíduo crítico não podia deixar de incomodar-se. Barrie escreveu sua narrativa expressando uma visão de mundo específica acerca da criança em geral e de pequenos abandonados, especificamente. Protagoniza seu livro um menino frágil e pequeno, que, por ser irreverente e recusar-se a obedecer às convenções, é abandonado. Nas circunstâncias da época, não é de estranhar a recusa de um menino de adentrar o mundo convencional.

A postura atrevida de Peter parece torná-lo alicerce de um novo modelo de sociedade, pautada em condutas consideradas tolas ou infantis quando comparadas às estratégias de um adulto que tenta vencer no mundo capitalista. Ele recusa-se a submeter-se às regras que tornam um homem respeitável, por isso não há lugar para ele neste mundo. Ele tem que partir e viver em Neverland, na Terra do Nunca, cujo nome sugere o caráter fantástico.

A personagem de Barrie é um infrator; logo, é abandonada e expulsa do convívio com o grupo. Crianças - ou pessoas - como Peter, que afrontam e ousam romper com as convenções são sempre punidas ou rejeitadas de algum modo. Entretanto, não é fácil calá-lo, 
pois ele permanece em uma ilha no fundo da mente das crianças ou no beijo escondido no canto da boca de certas mulheres, como Mrs. Darling.

$\mathrm{O}$ nome do protagonista que dá título à narrativa sugere algumas ideias presentes no romance. Peter, Pedro, em português, vem do latim Petrus: masculino de petra, pedra, rocha. A pedra bruta é símbolo de liberdade e contrapõe-se à talhada, índice de servidão, já que, como material para a construção, passou a representar sedentarismo e cristalização. O nome Pedro foi dado por Jesus a um de seus discípulos, considerado "pedra angular de sua igreja". Nas construções antigas, a pedra angular servia para alinhar a construção. Uma boa pedra tornaria um edifício adequado a seu projeto; por outro lado, uma pedra irregular alteraria toda a planta.

Peter é como a pedra bruta, símbolo de liberdade, pois recusa-se a subordinar-se às convenções. Nega-se a crescer no sentido de deixar-se domesticar, domar, dominar. $\mathrm{Na}$ sociedade em que seus pais se inserem, amadurecer corresponde à restrição da liberdade em prol das normas. No entanto, a liberdade, o atrevimento, a ousadia, a audácia são fulcrais para a idiossincrasia do rapaz. Importa ressaltar que não se trata de libertinagem, pois o menino prima pelas regras pautadas em sinceridade, honestidade, honra e pelo respeito, no universo que cria. Neverland destoa do mundo real, onde prevalecem a trapaça, a deslealdade e a perfídia, em prol do lucro. Peter rejeita essa postura e, como tem a memória fraca, esquece que há pessoas assim.

A alusão mitológica feita pelo sobrenome do rapaz é também relevante. Pan, em uma das versões do mito, foi abandonado, ao nascer, pela mãe, a ninfa Dríope, horrorizada pela aparência do bebê, o qual tinha chifres, pernas arqueadas como as de um bode e corpo coberto de pelos. Acolhida pelo pai, a criança nunca perde sua alegria e bom-humor, características que, mais tarde, seduzirão Eco. A vivacidade e energia de Pan fazem com que a ninfa queira unir-se a ele e lhe dê um filho. O casal vive feliz até que ela se depara com Narciso. A beleza deste rapaz faz com que a moça despreze o companheiro. A nova rejeição torna o deus um infeliz solitário. Talvez por isso ele seja repelente a ponto de seu nome dar origem à palavra pânico.

Também Peter Pan é abandonado. Ele decide deixar o carrinho de bebê quando escuta os planos de sua mãe para torná-lo um homem. Entretanto, os meninos que caem de seus carrinhos e perdem-se no parque têm seis dias para serem requisitados pelas mães. Caso não sejam procurados, são levados pelas fadas a Neverland. Com base nesse pressuposto, Peter, ao escolher não seguir o modelo de seus pais, foi abandonado. Isso se comprova pelo fato de, 
anos mais tarde, ele buscar sua mãe, mas encontrá-la com a janela fechada, brincando com outro menino, sem esperar por ele.

Peter, assim como o deus grego, assombra, causa pânico. Às mães, é uma ameaça, pois pode levar-lhes os filhos; aos apegados às tradições e boas maneiras - como o Capitão Gancho - configura um contratempo, uma vez que traz o escárnio, o deboche e a irreverência; às crianças, é um perigo, afinal segui-lo pode significar ser abandonado. Mas Peter é também um convite à liberdade, ao voo, à entrega ao mundo da imaginação. $\mathrm{O}$ deus Pan foi subjugado e abandonado duas vezes por sua aparência, Peter, por viver distante da sociedade, afrontar a lógica, o tempo e as normas comportamentais, também é rechaçado pelos pais de família e pelas pessoas ajuizadas.

Embora o menino queira uma mãe e busque em Wendy o carinho de que necessita, sua carência não é tão grande que o faça abandonar a integridade moral e psicológica; a liberdade é seu princípio mais caro. Assim, buscar crianças perdidas pode significar perseverar em sua causa. Na Ilha, ele pode propagar a importância de preservarem-se a imaginação e a expressão espontânea, irreverente e descompromissada com regras de etiqueta ou comportamentos sociais. Ainda que Wendy prefira ficar com seus pais a permanecer em Neverland, Peter volta para buscá-la para a limpeza da Primavera. Ele insiste. A faxina pode ter vários significados: para ele, parece consistir em um meio de não se perder, de manter um vínculo com o mundo real, afinal sua memória é tão frágil que chega a perguntar a Wendy se são mesmo pais dos meninos perdidos. A personagem tem dificuldade em diferenciar o real e o fictício. Para Wendy, viajar à Ilha da Fantasia é um modo de desanuviar-se e preservar sua infância. Peter configura-se, portanto, como uma alternativa para as amarras de uma realidade frustrante e castradora, é um escape psicológico.

Percebe-se, por conseguinte, que o protagonista de Barrie não odeia crescer, odeia as regras e os adultos que impedem o desenvolver de fantasias. A recusa de Peter é um primeiro movimento em busca de reforma. Há que se negar a seguir determinado padrão, para que outros se estabeleçam. Neverland representa uma ideologia descontraída, apenas vislumbrada em beijos escondidos no canto da boca de alguns adultos que conservam a jovialidade de pensamento e a irreverência de conduta, como Mrs. Darling, "a mais alegre de todas, [...] que dava piruetas." (BARRIE, s/d, p.10) Na Ilha, os meninos têm leis próprias, respeitam seu chefe porque têm orgulho de seus procedimentos e de astúcia. Peter tem o encargo de organizá-los e liderá-los. Juntos, eles criam a casa onde moram, imaginam seus banquetes e defendem seu território e seus interesses. 
Os meninos perdidos moram no subterrâneo, a casa reforça a ideia de inconsciente. É um espaço adequado apenas às crianças, um adulto não conseguiria ficar em pé no local. Vivem em um universo preparado especialmente para elas. Por configurar-se um esconderijo, representa também uma armadura, uma proteção. Como sementes embaixo da terra, essas crianças podem brotar como nova forma de vida. Na superfície, são perseguidas, pois o mundo dos adultos tem sua representação na Ilha pela figura dos piratas. O que está escondido na casa não pode vir à superfície enquanto Capitão Gancho - símbolo das regras tradicionais, vazias de sentido - não for eliminado. Semelhante a Peter, a casa protege as crianças e garante que seus sonhos permaneçam e possam acontecer.

Os índios, embora também sejam adultos, acabam aliando-se aos meninos quando percebem ter um inimigo comum: os piratas. Afinal, também a tribo tem regras próprias que não são bem vistas pelos homens comuns, por isso são alvo de perseguições.

A casa feita para Wendy é mágica, encantada, criativa e, como tal, participa da brincadeira. Assim que põem nela o chapéu de Michael como chaminé, a casa passa a produzir fumaça.

Wendy é trazida para a Ilha como uma mãe para os meninos. Nesse papel, ela se incumbe de impor regras e tomar cuidados essenciais ao bem-estar de uma criança. Suas normas, entretanto, não são vazias de sentido, mas condições que decorrem da preocupação com a saúde e com o crescimento do filho. A menina é mãe enquanto carinho, cuidado, doçura. Ela conta histórias, aconchega as roupas à noite, dá remédios. Peter e os meninos perdidos carecem desses desvelos, querem uma mãe assim. Sininho não é capaz de suprir essas necessidades, uma vez que ela também não teve mãe.

A figura materna é aludida na narrativa com frequência. $\mathrm{O}$ narrador expõe seu ponto de vista sobre a genitora como um ser tão altruísta que acaba vítima dos caprichos dos filhos. Também Gancho apresenta sua visão sobre a mãe. Ele nutre sentimentos contraditórios, por um lado, gostaria, assim como os demais piratas, de ter uma genitora porque sabe que ela se sacrifica por seus filhos. Por outro, não quer que os meninos tenham uma mãe, pois sua proteção fará com que aqueles não mais sejam presas fáceis.

Wendy permanece na Ilha até que percebe estar começando a esquecer seus pais. Os irmãos já não se lembram da mãe e consideram-na sua genitora. Consciente de que, dessa forma, colocará em risco sua família, ela decide partir e convida os meninos perdidos a acompanharem-na. Eles não hesitam: precisam de uma mãe. Só Peter recusa-se a deixar a Ilha. Wendy e os meninos partem para inserirem-se no seio familiar. Assim, abandonam a infância e suas próprias peculiaridades enquanto indivíduo e passam a representar um papel 
social. Em menos de uma semana de escola, entretanto, os meninos arrependem-se de deixar a ilha, mas é tarde demais, perderam sua habilidade de voar. A concepção de Peter sobre a vida em sociedade é, dessa maneira, reforçada.

O protagonista de Barrie sugere o voar como habilidade de quem tem pensamentos bons, imaginação e possui pozinho mágico. Voar representa o desejo de elevar-se, ainda que imaginariamente, desprender-se do concreto e colocar-se acima dos conflitos. A vida real consiste em um obstáculo essa habilidade porque limita e modela as pessoas.

Peter, na Ilha, é destemido e imbatível, mata seus inimigos e esquece-se deles, mas, no mundo real, assusta-se e grita de dor ao deparar-se com uma Wendy adulta. Por isso ela se compadecerá dele e promoverá sua existência, permitindo que sua filha a substitua nas limpezas de Primavera. Ela também é irreverente, afinal trata-se de uma mulher adulta autorizando a filha a cultivar o mundo da fantasia em que tudo é possível.

A faxina adquire, assim, mais um significado, é uma forma de garantir que outras crianças tenham contato com o universo imaginário, onde elas têm direito de tomar decisões, de expressar-se, de criar. Promover o contato com a Ilha da Fantasia significa dar oportunidade de viver com liberdade, irreverência e descompromisso com regras de etiqueta ou de conduta social. Nesse sentido, Peter torna-se pedra angular para um novo tipo de sociedade, baseada no respeito às características peculiares de cada ser, em cada fase de suas vidas. Vale quem é a pessoa e não sua linhagem, idade ou situação financeira.

$\mathrm{O}$ chefe dos meninos perdidos é uma criança enquanto ser irreverente e alegre, mas um homem no que tange o respeito pelo mais fraco e o auxílio ao próximo. O menino é responsável e piedoso com os abandonados, é impossível afastá-lo das crianças. Rapidamente os adultos fecham as janelas, ou impõem limites, mas a sombra de Peter não se vai, permanece entre os que creem nele.

A decisão do menino de "não crescer" adquire várias conotações, pois ele quer conquistar outras crianças a juntarem-se a ele. Corrobora essa hipótese o fato de a personagem tomar conta de crianças abandonadas, liderá-las em brincadeiras que estimulam a imaginação criadora e a liberdade. Pan ensina a voar, a valorizar os pensamentos maravilhosos para erguerem-se no ar, mesmo sabendo que "só se pode voar com a ajuda do pó das fadas." (BARRIE, s/d, p.32).

Além disso, ele está no cérebro de todas as crianças. Wendy o conhecia das vezes que ele a visitara enquanto ela dormia. Embora nunca tivesse acordado, a menina o conhecia. Sabia que ele era corajoso, irreverente e vaidoso, traços que irritam um adulto como Gancho, insensível, rigoroso e cruel, um menino de colégio que se torna uma figura pública, 
preocupada com linhagens e com as boas maneiras. O pirata é mero reflexo do obsessivo tique-taque do relógio na barriga do crocodilo que o persegue, sempre a lembrar das horas, símbolo das regras e convenções. Gancho quer amarrar as crianças para que não voem e matar Pan para que não ouse. O eterno menino não se intimida diante do atroz corsário, mas torna-se indignado perante as atitudes traiçoeiras deste homem:

Não foi a dor, mas a deslealdade que fizeram com que se sentisse indefeso. Ficou parado a olhar, horrorizado. Todas as crianças ficam assim da primeira vez que são tratadas injustamente. Pensam que devem ser tratadas com justiça. Depois de uma pessoa ser injusta para uma criança ela não deixará de gostar dessa pessoa, mas nunca mais voltará a ser a mesma. Ninguém consegue recompor-se de uma injustiça, ninguém, a não ser Peter. Já sofreu injustiças mas esquece sempre. Creio que é essa a verdadeira diferença entre Peter e os outros.(BARRIE, s/d, p.73)

Manter-se criança é conservar-se refratário aos males que o convívio com adultos cruéis pode causar. A juventude de Peter é eterna porque sua memória é fraca, ele não guarda rancor, não tem traumas, não envilece, não envelhece. Apresenta, outrossim, atitudes responsáveis: está sempre ao lado dos mais fracos, leva aos meninos perdidos uma mãe para contar histórias, remendar as roupas, aconchegar os lençóis à noite, e consente viver o papel de pai das crianças e respeitar as regras meticulosas de Wendy acerca de horário para dormir e remédios a tomar. O mais relevante, cabe ressaltar, é que o menino mora na mente de todas as crianças e só desvanece com a repressão à espontaneidade e à força imaginativa.

Enquanto Peter Pan configura-se um escape psicológico, o protagonista de Capitães da Areia representa a hipótese de um mundo mais justo e igualitário. Também a personagem de Jorge Amado é um menino abandonado que se chama Pedro, mas, diferente de Peter, ele não carrega referências mitológicas em seu nome, tem a alcunha "Bala". O termo sugere a ambiguidade do caráter do rapaz, já que pode referir-se tanto a um doce muito apreciado por crianças, como à munição, o que se associa ao universo da criminalidade, marginalidade em que o menino se insere.

Assim como Peter Pan, a maioria dos Capitães da Areia não teve vida escolar. Eles estão, por isso, livres da repressão imposta por

[...] um conjunto que forma uma política de coerções que são um trabalho sobre o corpo, uma manipulação calculada de seus elementos, de seus gestos, de seus comportamentos [...]. Como algo que aumenta as forças do corpo (em termos econômicos de utilidade), e diminui essas mesmas forças (em termos políticos de obediência). Em uma palavra: ela [a escola] dissocia o poder do corpo; faz dele por um lado uma "aptidão", uma "capacidade" que ela procura aumentar; e inverte, por outro lado, a energia, a potência que poderia resultar disso, e faz dela uma relação de sujeição estrita. (FOUCAULT, 1986, p. 127)

Dominadas por professores-repressores, as crianças da época têm suas habilidades para criar e inovar diminuídas. As instituições de ensino trabalhavam para a manutenção do 
poder, por conseguinte, adestravam seus educandos a tornarem-se mansos e dóceis, isentos de senso crítico. As personagens que protagonizam a narrativa de Amado são adversos a normas e à disciplina que cerceia movimentos e limita a capacidade de imaginar, criar ou contestar. São crianças desacostumadas a uma disciplina que cerceia movimentos e limita a capacidade de imaginar, criar ou contestar. Criados na liberdade das ruas, eles adquirem competências próprias de adultos, sabem como enganar, ludibriar, dissimular para conquistarem seu próprio alimento.

Ao contrário de Peter Pan, esses meninos são obrigados a amadurecer precocemente. Órfãs ou desamparadas em uma cidade injusta por privilegiar a classe dominante em detrimento dos menos afortunados, as crianças refugiam-se em um trapiche abandonado e decadente, onde procuram aconchegar-se e criar meios de evadir da miséria física e moral. Pirulito sublima sua condição pela devoção religiosa, Professor lê desenfreadamente e pinta quadros de pessoas tristes, Boa Vida toca violão, Gato adorna-se e conquista uma prostituta como amante. Volta Seca acompanha as proezas de seu padrinho, o cangaceiro Lampião, sonhando um dia acompanhá-lo. Somente Sem-Pernas remói a amargura de sua condição, alimentando planos de vingança e tratando os demais com ironia ferina. O chefe do grupo, Pedro Bala, sente-se imbuído de uma missão. Dirige os meninos com retidão, é dócil com quem merece e rigoroso quando é necessário. Porta-se como verdadeiro líder, pois se coloca em risco para defender o bem-estar dos demais.

Sua vocação manifesta-se ao saber sua origem. João de Adão (cujas iniciais coincidem com as do escritor), um trabalhador das docas que lidera greves e divulga ideais socialistas, é quem narra a Pedro sua história. O rapaz é filho de um líder grevista apelidado de Loiro, homem valente que morreu em passeata, defendendo os direitos de seus camaradas. João assegura a Pedro um lugar nas docas e chama o menino de capitão. $\mathrm{O}$ velho negro acredita na potencialidade do menino. Essa confiança fortalece Bala.

Diferentemente de Peter Pan, que se recusa a seguir os passos de seu pai, Pedro Bala orgulha-se de seu genitor, afinal trata-se de um homem sonhador, revolucionário que não se amolda ao sistema, e morre como mártir de uma causa nobre.

Bala porta-se como um capitão. É um líder idôneo, comanda com justiça, não abandona seu posto antes de salvar os que estão sob seus cuidados.

O abandono de meninos refere-se, neste romance, a um fato concreto. Não se trata do desprezo pela criança enquanto ser original, com necessidades e características específicas. Em Jorge Amado, o desamparo é físico, as crianças não têm lar, não têm fadas a quem recorrer, não recebem carinho. Vivem sob um telhado esburacado na esterilidade da areia. 
Sendo assim, eles não são responsáveis por estarem sós. Peter era um menino de família que passeava com a mãe em um bairro nobre de Londres. Pedro é deixado nas ruas da cidade baixa em Salvador, local popular e miserável. O menino da classe alta escolhe seu destino e cria um universo, como se fosse o colonizador da Ilha da Fantasia.

Peter torna-se figura importante em Neverland, sua postura diante dos demais é de superioridade, é temido e respeitado como superior pelos meninos. Afinal, ele é excessivamente vaidoso e orgulhoso de si, gosta de mostrar-se esperto e sagaz. Proíbe que falem em mães, faz suas as boas ideias alheias, tem que vencer sempre nas brincadeiras, a afetação é seu grande defeito.

Pedro, por outro lado, está marcado pela vida - inclusive fisicamente por um golpe de navalha - e destinado a mudar o destino de crianças abandonadas. Consciente de movimentos estudantis e proletários, o rapaz opta por torna-se um operário militante, perseguido pela polícia para defender sua causa e a dos seus. É um líder nato, mas comanda por destacar-se em bom-senso, astúcia e sagacidade capaz de livrar-lhe de situações adversas. Todos confiam nele.

A gargalhada dos meninos baianos sem motivo aparente contamina e enche o ar, como o som encantador das risadas de Peter. São crianças com missão de adultos.

Os capitães da areia têm leis rigorosas, todas relacionadas ao bem-estar do grupo. “Quando se é amigo, se serve ao amigo” (AMADO, 2009, p.94)

Também os capitães da areia encontram uma mãe / irmã de que necessitam na figura de Dora. Assim como Wendy, ela cuida dos meninos e participa de suas aventuras. Entretanto, ela não tem a oportunidade de crescer, adoece e morre em decorrência da angústia de ser encerrada em um orfanato. Do mesmo modo que Peter chora ao perceber que perdeu Wendy para a realidade e o amadurecimento, Pedro angustia-se diante da morte de sua amiga e querida namorada. Assemelham-se no riso e na dor.

Desprovidos da companhia feminina, eles têm que se dedicar a suas ideologias. Pan mantém sua busca por crianças que necessitem de seu apoio para fugir da realidade e entregar-se às fantasias, enquanto Pedro abraça a missão de organizar greves, dirigir partidos ilegais, clamar pela liberdade, revolucionar a ordem estabelecida.

A criança pobre brasileira que cair de um carrinho ou fugir de uma família não vai sonhar em ser acolhida por fadas, nem terá condições de criar mundos imaginários, ou desbravar ilhas e dominá-las. Não se trata de meninos que passeiam com babás em Kensington Park, mas de crianças inseridas em uma cidade desigual e preconceituosa que discrimina e castiga o diferente. Crianças pobres são perseguidas por guardas corruptos e 
cruéis que têm o prazer sádico em vê-las sofrer. Assim, Sem-Pernas é submetido a correr em círculos em uma sala pequena sob chicotadas de policiais que caçoam dele. Cai exausto por não aguentar a atividade com sua perna coxa e apanha até sangrar. Também a vida em família muitas vezes é assustadora. Almiro prefere a vida entre a criminalidade e a pederastia a voltar para casa.

Nesse contexto, Peter Pan não teria destino diferente do de Pedro Bala, abandonaria as fantasias infantis em prol de granjear astúcia para livrar-se da fome, das injustiças e das perseguições. Teria de nutrir malícia para lidar com adultos preconceituosos que o encarariam como um malfeitor e não como um menor carente. Não poderia ter memória frágil porque teria de lembrar-se da história de cada uma de suas cicatrizes como meio de evitar adquirir outras. Teria que saber que há apenas duas possibilidades de voo: ou a de Sem-Pernas que se atira a um precipício para escapar da fúria de guardas desumanos, ou a ousadia de clamar pela liberdade. "Porque a revolução é uma pátria e uma família". (AMADO, 2009, p. 262)

\section{Referências}

AMADO, Jorge. Capitães da Areia. São Paulo: Companhia das Letras, 2009.

ANDREOTTI, Azilde L.. O projeto de ascensão social através da educação escolarizada na década de 1930. Disponível em http://www.histedbr.fae.unicamp.br/navegando/artigos_frames/artigo_023.html. Acesso em 17 de maio de 2010.

BARRIE, James Matthew. Peter Pan. Lisboa: Publicações Europa-América, s/d.

FOUCAULT, Michel. Vigiar e Punir: nascimento da prisão. Petrópolis, Vozes, 1986. 